\title{
The New Age of Prophecy: The Chronicle of MATtheW of EDESSA AND ITS PLACE IN ARMENIAN HISTORIOGRAPHY
}

\author{
Tara L Andrews
}

\begin{abstract}
This paper makes an examination of the overall framework of the Chronicle of Matthew of Edessa, and looks anew at his interpretation of recent history within that framework. Following a long tradition of the use of prophecy and Biblical models to render the events of Armenian history explicable, Matthew has centred the Chronicle around two prophecies attributed to the eleventh-century clerical scholar Yovhannēs Kozren, themselves extended in the twelfth century under the influence of the Apocalypse attributed to Methodius. This pair of prophecies provide the framework for his argument that both the Byzantine emperors and the Armenian kings had abandoned their responsibility toward the Armenian people. The need to illustrate the truth of the vision laid out in Kozern's second prophecy affects Matthew's own presentation of the events about which he writes.
\end{abstract}

The Chronicle of Matthew of Edessa was composed in the years between 1120 and 1140 . The text covers nearly 180 years, from 951 to 1128. In it, Matthew describes the apogee of independent Armenia alongside the military expansion of Byzantium and the Muslim retreat in the Near East; the fall of Armenia to piecemeal Byzantine annexation and Byzantium's subsequent loss of its eastern territory to the newcomer Seljuk Turks, and the battles, court politics and sectarian tension that accompanied the Crusades. The chronicle is populated by Armenians, Syrians, Arabs, Greeks, Turks and Franks. It is a portrait of a land caught in centuries of cultural and religious upheaval.

Edessa, where Matthew lived and wrote, was at that time a majority-Christian city, populated primarily by Syrians and Armenians. During his lifetime it had been ruled by Byzantine governors, Armenian magnates caught between rival Byzantine and Muslim powers, and 
Latin Crusaders. He was consequently in a very good position to compose a history that set out the roles that the Armenian people had played in the events of the Near East in the eleventh and twelfth centuries.

The text can be divided into three books on the basis of Matthew's authorial interludes; these books cover progressively more events over progressively shorter time periods. Book One, covering the years between 401 and 500 of the Armenian era (AD 952-1052), has no preamble. ${ }^{1}$ Book Two covers the years 502 to 550 (10531102). It begins with the first of these interludes, a short statement of Matthew's motivations, and the methods he has so far employed in composing the Chronicle. Book Three covers the years 550 to 577 (1101-1129). ${ }^{2}$ It is prefaced with a longer exposition which gives most of the information we have about Matthew himself and his attitude toward the history he wished to write.

Matthew explains in the preface to Book Two that, for a long time, he had wished 'to write down for a future era the violent massacres, this dreadful wrath, which this Armenian people bore at the hands of the ... Turks, and their Roman brothers'. ${ }^{3}$ In order to do this, he says, he gathered information about 'the three races'; the Chronicle he produced treats many more than three races. He touches upon the history of Armenians, Byzantines, Turks, Arabs, Georgians, Syrians, Latins and Slavs. His work extends in its geographical scope to the limits of his known universe, yet it remains a text that reflects his distinctly Armenian outlook and philosophy of history. The way in which he arranged historical information in these books, and the explanations of his world-view given in his interludes, tell the reader much about the work he envisioned, his philosophy of history, and the difficulties he encountered in composing the text he intended to write.

The inclusive nature of Matthew's work - the attention he gives to all of the foreign peoples who had an influence on the Armenians is well within the bounds of Armenian historiography from the seventh century onward. The perspective that it represents, and the Armeno-centric interpretation that is given to events that had no direct relevance to Armenians, has turned the Chronicle into one of the most valuable sources for the history of Syria, Mesopotamia and the Caucasus region. The danger of such wide relevance is that the scholar who is not an Armenian specialist is tempted to treat the Chronicle as a straightforward account of the events in these regions, and in particu- 
lar to assume that Matthew, as neither a Latin nor a Greek participant, will have been relatively objective. A good, though dated, example of this tendency may be seen in Steven Runciman's History of the Crusades. He describes Matthew as 'a naïve man with a hatred for the Greeks and no great love for those of his compatriots who were Orthodox in religion. Much of his information about the Crusade must have been derived from some ignorant Frankish soldier; but about events in his native city and its neighbourhood he was very well informed' (1954: I, 334-35). Runciman, and many subsequent scholars of the Crusades who have not specialised in Armenian history or literature, use the Chronicle primarily as 'impartial' corroboration of other histories (see, e.g., Asbridge 2000: 12), and take much of Matthew's information at face value in a similar way. This has been nearly unavoidable to date - there is very little scholarship in the West specifically about Matthew or his Chronicle, and the lack of a critical edition renders the existing translations unreliable. Nevertheless, a literary interpretation of the Chronicle is sorely needed. Matthew was an Armenian monk in Edessa who claimed not to be a scholar; even if this claim simply reflects a common historiographical topos, it must be considered. His interpretation of events in Constantinople, Baghdad, Tiflis, Jerusalem or Edessa itself cannot be taken at face value. It must be understood in light of the Armenian historiographical tradition he was trying to follow, and the effect that tradition had on Matthew's judgements of the actors in his history.

In this article, I shall set out the parameters of Armenian historiography within which Matthew worked, and demonstrate that his Chronicle was a logical extension of that historiographic tradition. His goal was to illustrate the truth of the Biblical conception of Armenian history: God's children had strayed from righteousness; they were to be punished for the errors of their ways, but they could look forward to eventual redemption through God's mercy. The instrument through which Matthew worked was prophecy. I shall introduce the central prophecy of the Chronicle, and show how it became the structure on which the text as a whole was built.

\section{The Armenian historical tradition}

Matthew restates his aim in his prologue to Book Three: he 'saw that no one had the intention to investigate [recent history] or to collect records, to provide for future times a record of these massacres and 
tribulations for the good times, when the Lord God will fulfil his promise of the end time, when $\mathrm{He}$ will give to the faithful the era that will truly be full of every joy' (ME Z, 277-78; ME T, 181). This statement places Matthew firmly in an established tradition of Armenian historiography, in which the history of the Armenian people was viewed as the continuation of the Biblical history of the chosen people of God, and in which the reverses that the Armenians suffered represented divine chastisement that would eventually be followed by the divine restoration of Armenian fortunes.

A concise and valuable guide to Armenian historiography and its development from the fifth century on has been given by Jean-Pierre Mahé (1992). His premise can be summarised here as follows. The Armenian language was first given a written form in the beginning of the fifth century, nearly a century after Armenia's conversion to Christianity. The earliest Armenian historian, Koriun, gave in his Life of Maštoc 'a philosophy of history that viewed the Bible, and in particular the Old Testament, as a document of the history of God's chosen people. With the advent of the Christian era, therefore, the history of the new chosen people of God - that is, the Christians, and in this instance the Armenian Christians - was a legitimate extension of the Scripture they had inherited through their conversion. The Armenian historians who followed Koriun adopted this philosophy of history in their own works. The shocks of the seventh-century Arab conquest, and in particular the capture of Jerusalem in 638, forced the Armenian historians to account for the rise of this new power. ${ }^{4}$ Their histories perforce became universal in both chronological and geographical scope, in contrast to the tendency to focus on Armenia alone that had prevailed in fifth- and sixth-century works of history. ${ }^{5}$

The model of history that developed in the seventh and eighth centuries needed to account for the fact that the 'infidel' Arabs had a lasting hold on Jerusalem and most of the former Christian Orient, and that this sustained dominance could not be in opposition to God's will. An explanation was proposed by an anonymous seventh-century historian (Pseudo-Sebēos): the Christians had forfeited their possession of the Holy Land through their sinfulness, just as the Jews had earlier done through their rejection of Christ. The Muslim Arabs, considered by tradition to be the descendants of Abraham through his illegitimate son Ishmael, had pleased God with their discipline and their abstemious behaviour. Although they were not the true chosen 
people of God, they had been temporarily rewarded with possession of Abraham's patrimony, which they would be allowed to keep so long as they retained these virtues. By the eighth century, the historian Lewond could argue that the Muslims had forfeited this claim. He based his argument on an agreement between the katholikos Sahak III and the Arab governor Muhammad ibn Marwan: as long as the Muslims kept their promise to protect their Armenian subjects and respect their faith, God would allow them their domination over the Christian lands. The persecution of the Christians that followed during the eighth century, and the violent suppression of Armenian revolts, allowed Łewond to predict the eventual liberation of Armenia from Muslim rule. That liberation came in 884, with the crowning of Ašot I Bagratuni as king of the Armenians, recognised by both the Muslim caliph and the Byzantine emperor. The received view of Armenian history was thereby vindicated. The historians of the tenth century in particular often followed the lead of Movses Xorenac ${ }^{c} i^{6}$ in writing a history of the world from Adam to the present, in which the author drew on the genealogical information in the Bible, in the Greeklanguage histories of Eusebius, Josephus and others, and in the earlier Armenian tradition to show the development of the region (the Bagratuni kingdom, the Arcruni kingdom of Vaspurakan, the principality of Siwnik ${ }^{c}$, etc.) in which he wrote.

By the end of the eleventh century, Armenian fortunes had suffered a grievous reverse. The Armenian kingdoms had lost their independence; the primary kingdom of Ani was annexed to the Byzantine empire in 1045, and the Byzantines had proved unable to defend it against the invasions of the Seljuk Turks. The task of the Armenian historians who followed, beginning with the vardapet ${ }^{7}$ Aristakēs of Lastivert, was to make sense of this new calamity in the context of the historiographical tradition that had developed. Robert Thomson has explored the question of how Aristakēs came to terms with this disaster, and the way in which he drew on the lessons of the Old Testament and the tradition of Armenian historiography to explain what had occurred (Thomson 2003: 80-83).

In keeping with these traditions, Aristakēs attributed the recent misfortunes of the Armenian people to their own sins. Like PseudoSebēos and Łewond had to do regarding the Arabs, Aristakēs needed to account for the seemingly unstoppable success of the Turks; unlike 
his predecessors, he had no theory of Turkish descent from Abraham with which to work. He instead rejected the concept of predestination entirely. This is perhaps the most noteworthy feature of his history, according to Thomson; he refrains from the suggestion that the Armenians' misfortunes were unavoidable, and he likewise refrains from predictions of future salvation. His message is one of admonition: if the Armenians wish for an end to their troubles, they need only repent their sins.

For a contrast to Aristakēs, and as a representative of more 'traditional' patterns of Armenian historical philosophy, Thomson turns to Matthew of Edessa. Of Matthew's interpretation of history he says: 'The prophets predicted various happenings, which duly occurred. The Turkish invasions were thus inevitable. But they do not hold any further significance; they are not regarded as a trial or punishment which will induce the Armenians to repent and mend their ways' (2003: 85). Matthew's use of prophecy is the means by which he explains the inexplicable disaster of the Turkish invasions, and by which he promises a brighter future for the Armenians. This is more in keeping with the tradition of Łewond, who also rejected the notion that the Muslims were the chosen people of God, and provided the comforting prediction of the total restoration of Christian power in the future. The use of prophecy in the Chronicle, however, is much more than a means of describing recent calamity; as will be seen, it is the key to understanding the entire narrative thrust of the Chronicle.

\section{The prophecies of Yovhannēs Kozerin}

Although Matthew made reference to multiple prophecies throughout his text, the two most prominent, as Thomson notes, are the ones attributed to Yovhannēs Kozern. These prophecies are the vision at the core of Matthew's understanding of the history of the Armenians and of the world around them. The second prophecy in particular provides the basic outline of which the remainder of the Chronicle is an elaboration. ${ }^{8}$

Very little is known about the eleventh-century vardapet Yovhannēs Kozer̀n, also known as Yovhannēs Tarōnec'i. Aristakēs includes him among the notable intellectuals who were active during the reign of Gagik I Bagratuni, in the first two decades of the eleventh century; he is credited with authorship of a 'book of faith' (AL P, 26; AL T, 9). Although Aristakēs makes no mention of other works, 
Kozern is also known to have written a two-volume history of the Bagratunis, written at the behest of the katholikos Petros Getadarj (Ačaryan 1972: III, 566-67; see also K $\mathrm{K}^{\mathrm{i}}$ iwrtean 1967). The first book was a history from the time of Adam until the coronation of Ašot I Bagratuni in 884, and the second book covered the recent era, from 884 until the Armenian year 500 (1051/2). ${ }^{9}$ The majority of Kozern's history has been lost; only a few initial pages have been preserved in Matenadaran (Yerevan) MS 1775 (Połarean 1971: 174-75). Apart from the prophecies, Kozern appears on two occasions in Matthew's own Chronicle. He is first introduced as one of the Armenian scholars whom Basil II consulted at the time of the Easter dispute of 1007 (ME $\mathrm{Z}, 44$; ME T, 42); he is also named among the Armenian contingent, headed by the katholikos Petros, who paid a high-profile visit to Basil during his Eastern campaign, as the emperor wintered near Trebizond in January 1022 (ME Z, 50; ME T, 46).

His first prophecy is recorded for the year 478 (1029/30), after an astrological omen had been witnessed in Armenia and king Yovhannēs had sent his noblemen to seek an explanation from Kozern. His message was dire: the eclipse marked 1000 years since the baptism of Christ, and the thousand-year imprisonment of Satan was now at an end (cf. Revelation 20). Satan would now begin his ascendancy, men would fall into sin, the anger of God would be aroused and the Christians would be punished.

The second prophecy is recorded for the year 485 (1036/7). Again, an eclipse had been seen; again, the king and the katholikos Petros sent the Armenian noblemen, including Grigor Pahlawuni and Sargis Haykazn, to seek an explanation from Kozern. His response explained the radical change in fortunes that the Armenians were to undergo over the course of the next hundred years. He began by reiterating that the thousand-year imprisonment of Satan was at an end, the institutions of the Christian church would weaken, and the Christians themselves would fall into impiety, sin and schism. The Turkish invasions would follow shortly thereafter:

Hereafter there will be invasions by foreigners, the filthy forces of the Turks, the cursed sons of Ham, upon the Christian nations, and all the earth will be consumed by the edge of the sword; all the Christian nations will pass through sword and captivity; many districts will become depopulated, the power of the saints will be removed from the earth, many churches will be razed to their foundations, the mystery of 
Christ's cross will be suppressed ... And the land will be troubled by infidel nations, and the plants of the field will be clothed in bloody dew, and for sixty years the earth will be desolated through sword and captivity. And then the nation of valiant ones will come, known as Franks, and with a multitude of troops they will take the holy city Jerusalem, and the holy tomb that held God will be freed from captivity. And after this the earth will be ravaged for fifty years by the forces of the Persians through sword and captivity, and [it will be] seven times more than what the faithful have already suffered, and all the nations of the faithful in Christ will be terrified. (ME Z, 70-72; ME T, 59-60)

Gradually, according to the prophecy, the native forces would begin to strengthen themselves, until 'the Roman emperor, as if awakened from sleep' (ME Z, 73; ME T, 60), came forward to drive the Persians out, and to usher in a long period of peace and prosperity for the Christians.

As Thomson noted briefly in his comparison of Matthew with Aristakēs, the language in the prophecy has unmistakable parallels to the pseudo-Methodian Apocalypse, and in particular the description of the 'Last World Emperor' (Thomson 2001: 97). The Apocalypse attributed to Methodius of Olympus was written in the late seventh century around the region of Sinjar in Syria (Brock 1976), probably by a member of the Melkite church (Brock 1982). It was translated from Syriac into Greek, and thence into Latin, where it gained wide circulation. Although the text has a Melkite, and thus Chalcedonian, origin, and may have had a place in anti-monophysite polemic of the seventh century (Reinink 1992), it contains nothing that is overtly Christologically offensive to monophysite readers.

The Apocalypse has an uncertain history within Armenian literature. An Armenian translation was known to the thirteenth-century author Step 'anos Orbelian, who reproduced a portion of it in his own history. ${ }^{10}$ It had been translated by the eighth-century bishop Step $^{c}$ anos Siwnec ${ }^{c} \mathbf{i}$, but no complete text survives in Armenian. Its influence can only be guessed through similarity to the text of prophecies such as Kozern's. Even if one considers the text as it has been preserved in the Syriac, however, the broad parallels are clear. According to the Methodian prophecy

there will be, moving out against them, the king of the Greeks in great anger, and he will be awoken like a man who has shaken off his wine, 
whom they reckoned dead. He will move against them from the Cushite sea, and he will cast the sword and destruction in the desert of Yatreb and in the land of their fathers and will take captive their wives and their children. And the sons of the king of the Greeks will descend against them from the regions of the west, and they will exterminate with the sword the rest of them who remain in the Promised Land.

And fear will beset them on all sides. And they and their wives and children and their leader and all their possessions in the land of the desert of their fathers will be delivered to the might of the king of the Greeks. And they will be abandoned to the sword and to captivity and to death.

And the yoke of their slavery will be seven times more severe as their own yoke. And they will be in more severe affliction, in hunger and in thirst and in exhaustion. And they will be slaves, they and their wives and their children. And they will go into slavery for those who have served them. And their slavery will be a hundred times more bitter than their own.

And the land, which was bereft of its inhabitants, will be at peace. And the rest, who remain, will return, each to his own land and to the inheritance of his fathers. And Cappadocia and Armenia and Cilicia and Isauria and Africa and Greece and Sicily and all the rest, those of the captives who remained, and who were in the slavery of captivity, each will return to his land and to the house of his fathers.

And men will proliferate like locusts in the land that was dead. And Egypt will be desolated, and Arabia will be burned with fire, and the land of Hebron will be desolated, and the gulf will be pacified. And the whole fierceness and anger of the king of the Greeks will be cooled on all those who denied Christ. And there will be a great peace on the earth, as there has never been, because this is the last peace of the ending of the world. ${ }^{11}$

Direct echoes of this prophecy may easily be seen in the prophecy attributed to Kozern:

Then as if waking from sleep the king of the Romans will arise and come like an eagle against the Persian forces with a fearful multitude like sand on the shore of the sea; he will come inflamed like fire, and out of fear of him all creatures tremble, and the Persians and all the races of infidels shall take their flight to the other side of the great Gihon river. And then the king of the Romans will take and hold the whole land for many years; and all the earth will be renewed and he will lay the foundation for building and [the land] will thus be renewed like after the Flood; the offspring of men and beasts will multiply, 
fountains will gush forth streams of water. The fields will bear more fruit than before; and thereafter famine will fall on the Persian land for many years, until they attack and consume each other .... and they [the Romans] will take all the boys and girls and women to the Roman land in captivity; the house of the Persians will become desolate and depopulated by the forces of the Romans and all the sovereignty of the earth will settle in the hand of the king of the Romans. (ME Z, 73; ME $\mathrm{T}, 60)$

The language of the earlier parts of the prophecies do retain an echo of pseudo-Methodian symbolism (Thomson 2003: 86, n.46), but this direct correlation to the prophecy of the 'Last World Emperor' must have come from the hand which extended it. This raises some intriguing questions concerning the influence that the Methodian text had on the Armenian scholars of the late eleventh and early twelfth centuries. An influence can be seen in the language of Matthew's own prologues, where he speaks of 'the era [promised by God to the faithful for the future] that will truly be full of every joy' (ME Z, 279; ME T, 181), and states his determination to finish his history for the benefit of those who will live in that era.

The concrete timeline of events incorporated into the prophecy sixty years of Turkish oppression, followed by the capture of Jerusalem - is clearly not original. If one sets that portion aside, the text of the prophecy is a classic apocalyptic vision, with a safe round interval of fifty years during which the Christians are to suffer. It is not impossible that Kozern himself adopted the Methodian Apocalypse for the occasion of the thousandth anniversary of the Crucifixion, and that the text that Matthew preserves includes an interpolation into, rather than a full extension of, Kozern's original vision.

It is difficult to judge the authorship of the non-original parts of the prophecy. Matthew writes that 'we have spoken thus in front of rhetors and philosophers and deeply wise and well-versed researchers, and we have recommended our text to them, so that they might cast it into the furnace and make an examination, and we do not oppose this because we have no antagonism against the knowledgeable' (ME Z, 279; ME T, 182). Given the scholarly assistance that he evidently did seek, it might naturally be supposed that one aspect of this assistance might have been the provision of an extended version of Kozern's prophecy. On the other hand, Matthew demonstrates through the very authorship of the Chronicle that he is more educated than he pretends; 
the possibility cannot be discounted that the text of the prophecy he presents is at least partially his own work.

The date of the prophecy is almost certainly Matthew's own placement. An eclipse is recorded by Aristakēs, not for the year 485 (1036/7), but for 482 (1033/4) (AL P, 49; AL T, 38). Although Aristakēs has placed the event during the reign of Michael IV, which did not begin until April 1034, an annular solar eclipse did occur on 29 June 1033 that was visible from all of Europe, northern Africa and the western half of Asia. ${ }^{12}$ The date of this eclipse puts Kozern's words into their appropriate context: 'today 1000 years have passed since the tortures of the crucifixion of Christ' (ME Z, 68; ME T, 57). Kozern's calculation would thus be directly in line with the traditional calculation of the years since the birth of Christ. The prophecy must therefore have originally belonged to the year 482 (1033/4); Matthew's placement of it in $485(1036 / 7)$ gives a round number of sixty years to the First Crusade.

\section{The prophecy fulfilled: the structure of the Chronicle}

The visions of Turkish invasion, Crusader arrival and slow Christian strengthening expressed in the second prophecy form the narrative core of the entire Chronicle. The first book ends in the year 500 $(1051 / 2)$, at which point Matthew introduces himself to the reader. Levon Xač ${ }^{c} i k y a n$ has made a case for very close links between the texts of Matthew, the version of Kozern's prophecies that has survived independently (as published by Nikolai I. Marr), and a few extant fragments of the lost Chronicle of Yakob Sanahnec'i (Xačcikyan 1971). The importance of the second prophecy (whose text does not appear in the extant fragments of Sanahnec ${ }^{c} i$ ) to the structure of the Chronicle, together with the frequent appearances of Kozern himself in the text, suggests that Kozern's view of history was a major influence on Matthew's own. This could in turn explain why Matthew has used Kozern's prophecy - as extended by an unknown hand - to help frame the course of history before and after 1051.

The prophecy divides history into four distinct phases: the preinvasion period, the sixty years of Turkish conquest, the fifty years of Persian dominance, and the period after which the 'Roman emperor' has risen, driven out the Persians and inaugurated the promised period of renewed Christian rule. The Chronicle sets out to cover the first two 
of these, and most of the third. The books of the Chronicle are divided in a numerically neat fashion; although there is a rough correlation, they do not exactly fit these three phases. Book One portrays the apogee of the independent Armenian kingdoms, and the Byzantine empire at its height. The first prophecy of Kozern is placed shortly after the events that set in motion the loss of Armenian independence - the appearance of the Turks in Vaspurakan, the Arcruni emigration to Sebasteia, and the eastern campaign by Basil II against Gēorg of Georgia in which the Bagratuni king Yovhannēs-Smbat willed his kingdom to the empire after his death. For rhetorical purposes, Matthew has altered the years of the deaths of Basil II, Gēorgi of Georgia, and Senek'erim Arcruni, setting them in the year of this grave prophecy. In the years immediately following the 'main' prophecy of 485 (1036/7), he describes the quarrels between the various pro- and anti-Byzantine factions within the Armenian nobility that would bring about the fall of the kingdom of Ani in 1045, when the emperor Constantine Monomachos summoned Yovhannēs' young nephew and successor Gagik II to Constantinople and pressured him into giving up his kingdom. After the fall of Ani, the book shows the beginning of the Byzantine attempts to integrate the Armenian church into the Constantinopolitan one, which led to religious disputes and to a focus on the schism that had existed between the two churches since the Armenian rejection of the council of Chalcedon in 607. All of this elaborates the text of the prophecy:

Henceforth many schisms [will] enter the church of God through the idleness of the patriarchs, because they grow feeble and weaken and fail to make an examination of their faith and lose their minds. ... [The rulers and princes] cultivate their governance and rule for [earthly] recognition and not according to God. (ME Z, 69; ME T, 57-58)

Matthew describes the first sustained appearance of the Seljuk Turks in the closing entries of the book: their sack of the city of Arcn, and the battle of Kaputru that followed.

Concerning the appearance of the Turks in Anatolia, the prophecy predicted sixty years during which 'the earth will be desolated by sword and captivity', and the Christians would 'strive to destroy one another through murder and bloodshed ... and through their deeds they become companions of the infidel' (ME Z, 72; ME T, 59). These were the years 1036-1096; the bulk of them are covered in Book Two, 
and the themes of internecine strife and devastation in the wake of Turkish raids are its primary focus. Matthew covers the persecution of emigrant Armenians at the hands of their new Byzantine neighbours, and the escalating Byzantine pressure on the Armenian church to conform to the Chalcedonian orthodoxy of Constantinople. This is set against a backdrop of continual Turkish attacks in the east, which culminated in the sack of the old Armenian capital of Ani in 1064 and in the catastrophic Byzantine defeat at the 1071 battle of Manzikert. $\mathrm{He}$ also gives an account of the rise of the infidel and most wicked prince' Philaretos (ME Z, 206; ME T, 137), who was the first of the Armenian magnates to amass power of his own in the vacuum that was created after 1071. He uses all the epithets that had been expressed by Kozern about wicked and corrupt princes to describe Philaretos; his account of Philaretos' career ends with his apostasy and consequent fall from power. ${ }^{13}$ After the downfall of Philaretos, he turns almost exclusively to the Turkish and Fatimid campaigns in Edessa, Antioch and Aleppo, and the political establishment of the Muslim emirs in the region. The book ends shortly after the arrival of the First Crusade in 1096, the establishment of the first Crusader county at Edessa, and the capture of Antioch and Jerusalem, amid a profusion of ominous astronomical phenomena.

Matthew encountered difficulties when he came to write the third book of the history; his task was so difficult, in fact, that he put the history aside for seven years, hoping a scholar would finish it in his stead. He was not himself a scholar, he explained; he did not write in a refined style, and the task was 'not for our weakness nor for our sparse knowledge' (ME Z, 278; ME T, 182). The scholars and the philosophers had the ability he lacked to "conduct these examinations of the Old and New Testaments of God, and to clarify them through fearsome and brilliant analysis' (ME Z, 279; ME T, 183). In the tradition of Armenian historiography of which Matthew was a part, the composition of recent history - especially a history that so graphically illustrated God's punishment for human sin, and the redemption hinted at by the Christian re-capture of Jerusalem - must necessarily be inseparable from a sophisticated understanding of Biblical scripture, by which the full meaning of such profound events could be elucidated. It is precisely this understanding that he disclaimed for himself. 
For the third book in particular, the way before him was not clear. It was to cover thirty years, ending around the time that Matthew had originally set down his pen at the end of Book Two. According to the prophecy of Kozern upon which he was basing his work, these thirty years were to show the seeds of a glorious future that had not yet come, and would not come before 1146 . The 'Persians' had indeed arrived, in the wake of the Crusader capture of Jerusalem, to ravage the land once more; the 'Romans' had been driven out, and the Latin and Armenian princes were under constant pressure. Matthew must maintain emphasis on the continued suffering of the Christians, and explain the sins for which these sufferings were punishment, but he must also look ahead to the Christian princes - the 'remnants of the former armies' who would 'begin to strengthen little by little' and establish themselves in the conquered territory. He must show the direction from which the eventual redemption of the Christians from the Muslim oppressor would come. The events of the first thirty years of the twelfth century constituted a tale of ambiguity moderate successes with frequent reverses - and the task that Matthew faced was to find a suitably prophetic interpretation for this mixed course of history.

Although he felt himself unqualified, Matthew could not in the end leave his work unfinished. He had resolved to let a more skilled scholar take up the task, 'and indeed we saw everyone shrink from this history-writing' (ME Z, 282; ME T, 184). He concluded that he was, perhaps, the only one who could finish it after all: 'It is impossible that anyone else could find these things out or could collect [records of] all the different nations and kings, patriarchs and princes, to set all the times in chronological order' (ME Z, 280; ME T, 183). He realised that his inability to find a more qualified continuator was evidence that God had appointed the task specifically for him, although he felt that he lacked the necessary talent: 'It is God's habit to require some useful work from the weak and the inconsequential; so we see the hive of bees and marvel at their organisation, that from the lightness of their bodies [which are] as nothing, all the sons of man enjoy their sweetness, and their products meet the needs of the saints, and before saints and kings their [honey] is praised' (ME Z, 278-79; ME T, 182). Finally, he understood that he was running out of time: 'We saw that time continued to pass, and the outpouring and trickling and diminution of time was evident to us, and that there is no 
cessation of mankind upon the earth, but it has made clear the transformation of the present into the future' (ME Z, 282; ME T, 184). Matthew therefore took up his pen once more, to chronicle as best he could the mixed fortunes of the Armenians and other Christians in the early twelfth century.

The text of Book Three focuses primarily on the activities of the Crusader princes in Edessa and Antioch. The Crusaders took control of Edessa within a year of their arrival; the bulk of Matthew's adult experiences would have been profoundly affected by his new Latin lords. The city was taken by Baldwin of Boulogne, the brother of the future Godfrey I of Jerusalem, after the Armenian governor, $\mathrm{T}^{c}$ oros, was deposed and killed by the townspeople. Matthew follows the fortunes of Baldwin in Edessa and of the other Crusaders as they capture Antioch and Jerusalem, and as they come under immediate counter-attack from the Muslims. The attitude he displays toward the Crusaders is profoundly mixed - on the one hand, they are valiant; on the other hand, they are greedy. At times, he portrays them as compassionate and honourable, at other times, they are suspicious of each other, dishonourable and quick to break their oaths, and lacking in compassion. His descriptions often include them as fellow 'faithful Christians', and just as often set them in opposition to the Christian population, speaking of the troubles 'that they brought upon the faithful' as if the Latins were not Christians themselves. ${ }^{14}$

Matthew's portrayal of the Crusaders reflects the difficulty that he faced in assigning them a clear role within the framework of history as set out by the prophecy. They had very little intrinsic role in the remainder of Kozern's prophecy - the fifty years of further suffering at the hands of the Persians, followed by the coming of the victorious Roman Emperor - but they had become far too relevant to ignore. The capture of Jerusalem, however, was far too momentous to be passed over in silence by any prophecy on which a history was to be based. At the same time, although it had been a stirring victory for Christendom, there had been a sufficient number of successful counter-attacks by the various Muslim emirs to prevent the wholesale expulsion that the Crusaders, and the proponents of the prophecy of the Last World Emperor, had hoped for. The resulting prophecy of Kozern thus includes a reference to the Crusaders, but does not assign them a specific role in the final victory over the 'Persians'. Matthew himself makes reference to a certain Mark the Hermit, who died in 
1105; he writes that 'he prophesied about the Franks, when they took the holy city of Jerusalem, that the Persian nation would again strengthen itself and would come with the sword up to the coast of the great sea, which indeed we have seen' (ME Z, 301; ME T, 196). Mark was evidently not one who believed that the Christians had yet been sufficiently punished for their sins; as Matthew reports, he continued his prophecy with the warning that "belief [in God] will diminish and the doors of the holy church will be closed, [people] will be blinded to good works, they will forget the commandments of the holy Gospel of Christ, sin and evil will inundate the earth, and the sons of man will waver like the sea in sin, all the nations of the faithful will forget righteousness' (ME Z, 301; ME T, 196-97). This language is strongly reminiscent of the first Kozern prophecy, without the promises of punishment and salvation that appear in the second. It suggests a feeling of despair that, five or six years after the capture of Jerusalem, no real salvation had yet come to the eastern Christians.

By the time Matthew was writing Book 3, the sense of despair was less acute, and hopes of eventual Christian victory had revived. Although Matthew does not seem to have looked to the Crusader princes to lead the revival of Christendom that would end with the appearance of the Last World Emperor, his expectations of the prophecy's fulfillment remained high. He records the appearance of an 'awesome, great and marvellous comet' in February 1106; 'the wise men and the experienced ones said "This is a royal star; a king will be born in this year who will rule over all creation, and his kingdom will stretch from sea to sea, like the great Alexander of Macedon"' (ME Z, 304; ME T, 198-99).

Near the end of the book, Matthew begins to chronicle the rise of David 'the Builder' - the Bagratuni king of Georgia who, over the course of the $1120 \mathrm{~s}$, began to expand his power into the territory of the former Armenian kingdoms that had been under Turkish rule for over fifty years. This was the beginning of two centuries of Georgian dominance in that region. ${ }^{15}$ The rise of David, and the continued Georgian strengthening under David's son and successor Demetrios, neatly represented the 'gradual strengthening' that must take place before Kozern's Roman Emperor - the Last World Emperor of the pseudo-Methodian Apocalypse - could arise and usher in the new period of prosperity that Matthew anticipated. The third book is unfinished; Matthew's last entry, for the year 577 (1128/9), provides an 
unsatisfying end to his narrative. It is impossible to say whether he envisioned an heir of David Bagratuni as the 'king of the Romans' who would redeem the Christians, or whether he looked to the strengthening of the Komnenian emperors of Byzantium or the Crusader lords of Outremer as the means of this redemption. It is nevertheless possible to trace Matthew's attempts to organise the historical information he had for Book Three into a narrative that supported the prophetic picture of the 'fifty years' of 'Persian' attack, utter Byzantine collapse, and limited renewal of the Christian nobility that remained in the region.

\section{Conclusion}

When Matthew came to write his Chronicle, he was drawing upon a well-established model within the Armenian historiographical tradition. The history of the Armenians, as Christians of the 'true' (that is, non-Chalcedonian) faith, was the history of the chosen people of God, and could be acceptably drawn from Biblical patterns with which he was familiar. The recent reverses that the Armenians had suffered were signs of God's displeasure with His people; they must undergo a period of suffering as consequence for their sins, but they would eventually be redeemed through God's mercy, and the infidel oppressors who were the agents of divine punishment would be driven out.

Matthew was able to adopt a pair of prophecies, attributed to and probably authored by the vardapet Yovhannēs Kozern, to encapsulate this philosophy of history. The second of these prophecies extended by a twelfth-century author, either Matthew himself or an unknown collaborator, provides the structure around which the rest of the Chronicle was composed. This structure was followed in a straightforward manner for Books One and Two of the Chronicle; for Book Three, however, the prophetic structure of the history was overtaken to some extent by the inconclusive nature of events. Matthew was able to describe recent events neither as continued punishment nor as an unmistakable beginning of divine redemption. In attempting to paint a complex picture of varied fortunes for the Armenians and other Christians, he gives a conflicting account of virtuous yet villainous Crusaders, infidel but often merciful Turks, and the gradual revival of Bagratuni strength in Georgia near the end of a book that is nevertheless labelled as an account of 'massacres and suffering'. His complexity descended occasionally into confusion, but his aim is served: 
to leave 'a record of these trials and tribulations for the good age, when the Lord God will give what He promised in ... the era that will indeed be full of every joy' (ME Z, 277-78; ME T, 181). 
Bibliography

Primary sources

Aristakēs Lastivertcci. Patmut îwn Aristakisi Lastivertc 'woy. Ed. K. N. Yuzbašyan. Yerevan: Haykakan SSR Gitut'iunneri Akademiayi Hratarakčcut'yun, 1963. Referred to as 'AL P', followed by page number.

[-]. Récit des malheurs de la nation arménienne. Traduction française avec introduction et commentaire par Marius Canard et Hayk Berberian. Brussels: Éditions de Byzantion, 1973. Referred to as 'AL T', followed by page number.

Matt ${ }^{`} \bar{e}$ os Urhayec' $i$ (Matthew of Edessa). Žamanakagrut ${ }^{c} i w n$. Ed. Mambrē Melik'c-Adamean and Nersēs Tēr-Mik'ayēlean. Vałaršapat, 1898. Ref. to as 'ME Z', followed by page number.

[- ]. Armenia and the Crusades. Trans. Ara E. Dostourian. Belmont, MA: University Press of America, 1993. Referred to as 'ME T', followed by page number.

Mxit'ar Goš. The Lawcode [Datastanagirk'] of Mxit'ar Goš. Trans. Robert W. Thomson. Dutch Studies in Armenian Language and Literature 6 . Amsterdam: Rodopi, 2000.

Pseudo-Methodius. Die syrische Apokalypse des Pseudo-Methodius. I. Text. II. Übersetzung. Ed. and trans. by G. J. Reinink. Corpus scriptorum christianorum orientalium; vol. 540541. Leuven: Peeters, 1993.

Step'anos Orbelian. Histoire de la Siounie. 2 vols. Trans. Marie Félicité Brosset. St. Petersburg: 1864, 1866.

Rewriting Caucasian History: the Medieval Armenian Adaptation of the Georgian Chronicles. The original Georgian texts and the Armenian Adaptation. Trans. Robert W. Thomson. Oxford oriental monographs, New Series 3. Oxford: Clarendon Press, 1996.

\section{Secondary sources}

Ačaryan, H. (1972). Hayoc ${ }^{c}$ Anjnanunneri Bararan. 3 vols. Beirut: Erevani Petakan Hamalsaran.

Asbridge, Thomas S. (2000). The Creation of the Principality of Antioch 1098-1130. Woodbridge: Boydell Press. 
Bozoyan, Azat (1988). Byuzandiayi arevelyan k'ałak'akanut 'yunēe ev Kilikyan Hayastanē ŽB dari 30-70-akan t'vakannerin. Yerevan:

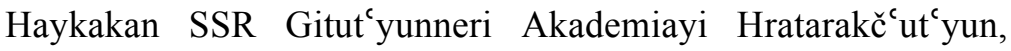
1988)

Brock, Sebastian (1976). 'Syriac Sources for Seventh-Century History.' Byzantine and modern Greek Studies 2: 17-36.

- (1982). 'Studies on the First Century of Islamic Society.' In Syriac Perspectives on Late Antiquity. Ed. G. H. A. Juynboll. Carbondale; Edwardsville; Southern Illinois UP. 9-21.

Dédéyan, Gérard (2003). Les Arméniens entre Grecs, Musulmans et Croisades. 2 vols. Lisbon: Fundação Calouste Gulbenkian.

Dostourian, Ara E. (1993). See Armenia and the Crusades.

Espinak, Fred, and Jean Meeus (2004). NASA's GSFC: http://eclipse.gsfc.nasa.gov/SEcat5/SE1001-1100.html [last checked 2009-Mar-04]

Garsoïan, Nina (1994). 'Reality and myth in Armenian history.' In The East and the Meaning of History: international conference (23-27 November 1992). Studi orientali 13. Rome: Bardi. 13643.

— (2003-04). 'L'Histoire attribuée à Movsēs Xorenac'i: Que reste-til à en dire?' Revue des études arméniennes 29: 29-48.

Greenwood, Timothy (2002). 'Sasanian Echoes and Apocalyptic Expectations: A Re-evaluation of the Armenian History Attributed to Sebeos.' Le Museon 115: 323-97.

— (2007). 'Armenian Sources.' In Byzantines and Crusaders in Non-Greek Sources, 1025-1204. Ed. Mary Whitby. Proceedings of the British Academy. Oxford: Oxford UP. 221-52.

Halfter, Peter (1996). Das Papsttum und die Armenier im frühen und hohen Mittelalter: von den ersten Kontakten bis zur Fixierung der Kirchenunion im Jahre 1198. Cologne: Böhlau Verlag.

K'iwrtean, Y. (1967). 'Yovhannēs Vardapet Kozer̀n.' Handēs Amsorya 81: 1-16.

MacEvitt, Christopher (2007). 'The Chronicle of Matthew of Edessa: Apocalypse, the First Crusade, and the Armenian Diaspora.' Dumbarton Oaks Papers 61: 157-81. 
Mahé, Jean-Pierre (1992). 'Entre Moïse et Mahomet: Réflexions sur l'historiographie Arménienne.' Revue des etudes arméniennes 23: $121-53$.

Połarean, Norayr (Episkopos) (1971). Hay Grotner (5-15 tar). Jerusalem: Tparan Srboc ${ }^{c}$ Yakobeanc'.

Reinink, G. J. (1992). 'Ps. Methodius' Concept of History.' In The Byzantine and Early Islamic Near East I. Problems in the Literary Source Material. Ed. Averil Cameron and Lawrence I. Conrad. Princeton: Darwin Press. 149-87.

- (1993). See Pseudo-Methodius. Die syrische Apokalypse des Pseudo-Methodius.

Runciman, Steven (1951-1954). A History of the Crusades. 3 vols. Cambridge: Cambridge UP.

Thomson, Robert W. (1996). See Rewriting Caucasian History.

- (2001). 'The concept of 'history' in medieval Armenian historians.' In Eastern approaches to Byzantium: papers from the Thirty-third Spring Symposium of Byzantine Studies, University of Warwick, Coventry, March 1999. Ed. Antony Eastmond. Aldershot: Ashgate. 89-99.

- (2003). 'Aristakes of Lastivert and Armenian Reactions to Invasion.' In Armenian Karin/Erzurum. Ed. Richard G. Hovannisian. Costa Mesa, CA: Mazda Publishers. 73-88.

Xačcikyan, Levon (1971). 'Yakob Sanahnec'i žamanakagir XI dari.' Banber Erevani Hamalsarani 13: 22-47.

\footnotetext{
${ }^{1}$ The traditional Armenian calendar is a solar one with no leap year; it began in AD 552. During the eleventh and early twelfth centuries, the new year fell in roughly February or March; one must therefore add either 551 or 552 to arrive at the Gregorian year.

${ }^{2}$ The division of the text in all printed editions and translations places the end of Book Three after the entry for 585 (1136/7); however, as both Timothy Greenwood and Azat Bozoyan have argued, Matthew's own text almost certainly ended with the entry for 577 (1128/9); see Greenwood (2007: 234) and Bozoyan (1988: 27-29).

${ }^{3}$ Armenian text: ME Z, 112-13. All translations from this are my own. For a published English translation of the full Chronicle, see Dostourian (1993).
} 
${ }^{4}$ The practical reality of Armenian history, throughout the Persian domination of the fifth century and the later Muslim rule, was one in which the local Christian rulers were able to find an accommodation with their non-Christian overlords. In the myth of Armenian history as it arose through historiographical and other literature, however, the conflict between 'faithful' Armenians and 'infidel' outsiders was paramount. For a good discussion of this paradox, see Garsoïan (1994).

${ }^{5}$ This universality partially arose from an attempt to fit the events of recent history into an apocalyptic framework, such as the vision of Daniel, which appears in many later Armenian histories including that of Matthew and that attributed to Sebēos. For the apocalyptic perspective of pseudo-Sebēos in particular, see Greenwood (2002).

${ }^{6}$ The dating of the history of Xorenac ${ }^{c} i$ has been hotly debated. The author himself claimed to be writing his work in the fifth century; certain features of the text, and the fact that it had a huge influence on Armenian historians after the eighth century but not before, suggest an eighth-century dating. See, e.g., Garsoïan (2003-04). For the purposes of his argument, Mahé treats the history of Xorenac ${ }^{c} i$ as an eighthcentury text.

${ }^{7} \mathrm{~A}$ vardapet is an Armenian clerical scholar; there is almost no evidence of a tradition of secular scholarship within Armenia at this time. The thirteenth-century author Mxit ${ }^{`}$ ar Goš discussed their training and duties in his law code; see The Lawcode (Datastanagirk') of Mxit'ar Goš, pp. 43-46.

8 This observation has also recently been made by Christopher MacEvitt (2007: 179), although he did not elaborate this particular point.

${ }^{9}$ One possible explanation of Aristakēs' failure to mention Kozeŕn's own history is that, as he was describing the intellectual activity that flourished during the reign of Gagik I, he restricted his list to those activities in which the vardapets engaged during that period.

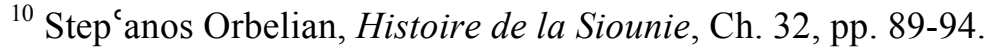

${ }^{11}$ Pseudo-Methodius, Die syrische Apokalypse des Pseudo-Methodius, XIII.11-15. My translation is from the German (II, 62-65) with reference to the Syriac (I, 38-40). 


\footnotetext{
${ }^{12}$ Eclipse predictions by Espinak and Meeus (2009).

${ }^{13}$ For a fuller discussion of the question of Philaretos' apostasy, see Dédéyan (2003: I, 243-46).

${ }^{14}$ See, for instance, the siege of Aplast ${ }^{\mathrm{c}}$ an in 554 (1105/6): ME Z, 302-4. Unlike the Byzantines, the Armenians rarely came into overt confessional conflict with the Latin church; the spirit tended instead to be one of conciliation. For an overview of relations between the two churches during this period, which culminated in a declaration of union at the synod of Jerusalem in 1141, see Halfter (1996: 122-43).

${ }^{15}$ The primary source for the rise of David Bagratuni is the book known as the Georgian Royal Annals or the Georgian Chronicles; see Thomson (1996).
} 